\title{
Volatile and Phenolic Composition of A Chardonnay Wine Treated with Antimicrobial Plant Extracts before Malolactic Fermentation
}

\author{
Juan J. Rodríguez-Bencomo
}

Dept. of Biotechnology and Microbiology, Institute of Food Science Research (CIAL)

CSIC-UAM. C/Nicolás Cabrera 9, Campus de Cantoblanco

Autonoma University of Madrid. 28049 Madrid, Spain

Tel: 34-910-017-822Ｅ-mail: jrbencomo@ifi.csic.es

\section{Almudena García-Ruiz}

Dept. of Biotechnology and Microbiology, Institute of Food Science Research (CIAL)

CSIC-UAM. C/Nicolás Cabrera 9, Campus de Cantoblanco

Autonoma University of Madrid. 28049 Madrid, Spain

Tel: 34-910-017-995Ｅ-mail: almugarcia@ifi.csic.es

\section{Pedro J. Martín-Álvarez}

Dept. of Biotechnology and Microbiology, Institute of Food Science Research (CIAL)

CSIC-UAM. C/Nicolás Cabrera 9, Campus de Cantoblanco

Autonoma University of Madrid. 28049 Madrid, Spain

Tel: 34-910-017-967Ｅ-mail: pedroj.martin.alvarez@csic.es

M. Victoria Moreno-Arribas

Dept. of Biotechnology and Microbiology, Institute of Food Science Research (CIAL)

CSIC-UAM. C/Nicolás Cabrera 9, Campus de Cantoblanco

Autonoma University of Madrid. 28049 Madrid, Spain

Tel: 34-910-017-902Ｅ-mail: victoria.moreno@csic.es 
Begoña Bartolomé (Corresponding author)

Dept. of Biotechnology and Microbiology, Institute of Food Science Research (CIAL)

CSIC-UAM. C/Nicolás Cabrera 9, Campus de Cantoblanco

Autonoma University of Madrid. 28049 Madrid, Spain

Tel: 34-910-017-966 E-mail: b.bartolome@csic.es

Received: June 21, 2014 Accepted: July 6, 2014

doi:10.5296/jas.v2i2.5980 URL: http://dx.doi.org/10.5296/jas.v2i2.5980

\begin{abstract}
Previous studies have proven the potential of antimicrobial plant extracts to delay malolactic fermentation (MLF) in red wines. With the final end of extending their applicability in oenology, the aim of this study was to investigate whether the addition of antimicrobial extracts (from eucalyptus leaves and almond skins) to white wines (i.e., Chardonnay wine), as a way to control MLF, would affect wine organoleptic properties, in particular those related to their volatile and phenolic composition. Although addition of both extracts led to statistically significant changes $(\mathrm{p}<0.05)$ in the concentration of several volatile and phenolic compounds, only few of them showed contents higher than their sensory thresholds, meaning that the changes observed in their concentration could slightly affect the final wine aroma and astringency. However, use of the extracts in the elaboration of white wines needs to be assessed in future experiments at winery scale, including wine sensorial analysis.
\end{abstract}

Keywords: White wine, Malolactic fermentation, Antimicrobial phenolic extracts, Volatile compounds, Phenolic compounds, Aroma

\title{
1. Introduction
}

The malolactic fermentation (MLF) is the process by which the lactic acid bacteria (LAB) convert the L-malic acid into L-lactic acid. This fermentation contributes positively to wine quality, especially for red wines, by means of: wine deacidification, microbiology stability and sensory complexity of wine. The nature and concentration of those volatile compounds responsible for wine aroma are known to be affected by the MLF process, depending on the LAB strain, grape variety and the winemaking practices (Matthews et al., 2004). Particularly, the MLF process could lead to: a) the formation of new volatile compounds from grape compounds such sugars, amino acids, b) to the transformations of volatile compounds initially present in grapes or generated during alcoholic fermentation, and c) to the adsorption of volatile compounds by bacteria wall cells (Pozo-Bayón et al., 2005; Lerm et al., 2010).

However, an uncontrolled progress of LAB growth and, therefore, of MLF process may cause alterations on the organoleptic quality of the wine, and even, on its safety (e.g. production of 
biogenic amines) (Bartowsky, 2009). In order to prevent from these hazards, sulphites $\left(\mathrm{SO}_{2}\right)$ are added during the elaboration of wine. $\mathrm{SO}_{2}$ is one of the most versatile and efficient additives employed in winemaking due to its antioxidant and antiseptic properties, especially against LAB. Owing to the potential risks of sulphites to human health, in recent years, there is a growing tendency to reduce their concentration in musts and wines. This has promoted a concern for the development of new alternatives to the use of sulphites in oenology (Santos et al., 2012). Some of these alternatives emphasize the use of natural antimicrobial compounds from plants (e.g. phenolic compounds), animals (e.g. enzymes such as lysozyme) and microorganisms (e.g. bacteriocins) (Abee et al., 1995).

Several studies have evaluated the antimicrobial effect of phenolic compounds (hydroxybenzoic acids and their derivatives, hydroxycinnamic acids, phenolic alcohols and other related compounds, stilbenes, flavan-3-ols and flavonols) present in wine and grape against oenological LAB (Reguant et al., 2000; García-Ruiz et al., 2009; 2011). Recently, our group has studied the antimicrobial effect of different plant phenolic extracts against six oenological LAB and two acetic acid bacteria in culture. Later, and as a first approach for testing their technological applicability in oenology, an extract from eucalyptus leaves was added to red wines before MLF. The wines treated with the eucalyptus extract were characterized by a lower ratio of malic acid transformation than the control wines (not addition) (Bartolomé et al., 2011; García-Ruiz et al., 2012). Moreover, organoleptic characteristics of the extract-treated wines seemed not to be substantially modified, as minor changes were observed in their phenolic and volatile composition (García-Ruiz et al., 2013).

Although MLF is mainly carried out in red wines, there are certain white cultivars with a specific organoleptic profile such as Chardonnay and Burgundy for whose wines occurrence of MLF is recommended (Bauer \& Dicks, 2004). Therefore, the aim of this study was to investigate whether the addition of antimicrobial extracts, as a way to control MLF in white wines, would affect wine organoleptic properties, in particular their volatile and phenolic composition. For that, a Chardonnay wine has been treated, before MLF, with two antimicrobial extracts from eucalyptus leaves and almond skins, whose antimicrobial activity against LAB and acetic acid bacteria has been previously tested (García-Ruiz et al., 2012). Differences in the concentration of main volatile and phenolic compounds between extract-treated wines and control wines (no extract addition) have been evaluated, and their possible impact on wine organoleptic properties has been discussed.

\section{Materials and Methods}

\subsection{Reagents and Solvents}

Pure volatile compounds were supplied by Aldrich (Gillingham, UK), Fluka (Buchs, Switzerland), Riedel de Häen (Seelze, Germany) and Firmenich (Geneva, Switzerland). Pure phenolic compounds were purchased from Sigma (St. Louis, MO, USA), Extrasynthèse (Genay, France), Phytolab (Vestenbergsgreuth, Germany) and Scharlau (Barcelona, Spain).

Two commercial phenolic extracts were kindly provided by Biosearch Life S. A. (Granada, Spain): an extract from eucalyptus leaves ( $89 \mathrm{mg}$ of gallic acid equivalents/g) and an extract 
from almond skins (165 mg of gallic acid equivalents/g).

\subsection{Malolactic Fermentation Assays in Wine}

A white wine (var. Chardonnay) (vintage 2009) was elaborated at Bodegas Miguel Torres S.A. (Catalonia, Spain), following their own winemaking procedures. The alcoholic fermentation was carried out in a controlled form in stainless steel at $25 \pm 2{ }^{\circ} \mathrm{C}$. The end of $\mathrm{AF}$ was established by measuring the alcohol degree $(14 \% \mathrm{v} / \mathrm{v})$, total acidity $(7.90 \mathrm{~g} / \mathrm{L}$ tartaric acid $)$, volatile acidity $(0.35 \mathrm{~g} / \mathrm{L})$, and the residual sugar amount $(2.25 \mathrm{~g} / \mathrm{L})$; the wine $\mathrm{pH}$ at the end of alcoholic fermentation was 3.12. MLF experiments were conducted at laboratory scale, sterile conditions, in $250 \mathrm{~mL}$ flasks as indicated in previous studies (García-Ruiz et al., 2012). Both the eucalyptus leaves and almond skins extracts were dissolved in $200 \mathrm{~mL}$ wine at a concentration of $(2 \mathrm{~g} / \mathrm{L})$. The malolactic starter was comprised of a mix of three Oenococcus oeni strains previously isolated by the winery, and was inoculated in wine at $3 \%(\mathrm{v} / \mathrm{v})$. A control containing no extract was also prepared for MLF assays. Wines containing phenolic extracts and control wines, all in duplicate, were incubated at $25^{\circ} \mathrm{C}$ in the dark. The content of L-malic acid was monitored in wines using an enzymatic kit (Megazyme International Ireland Ltd., Bray, CO. Wicklow, Ireland), with determinations being carried out in duplicate. MLF was considered over when the content of L-malic acid was $\leq 0.05 \mathrm{~g} / \mathrm{L}$. Wines after MLF were preserved $\left(-20^{\circ} \mathrm{C}\right)$ for analysis.

\subsection{Volatile Composition Analysis}

Analysis of wine volatile compounds was carried out as previously described (García-Ruiz et al., 2012). Briefly, wine ( $8 \mathrm{~mL})$, the internal standards solution (3,4 dimethylphenol, $400 \mathrm{mg} / \mathrm{L}$; 3-octanol, $10 \mathrm{mg} / \mathrm{L}$; and methyl nonanoate, $2.5 \mathrm{mg} / \mathrm{L})(40 \mu \mathrm{L})$ and $\mathrm{NaCl}(2.3 \mathrm{~g})$ were added to $20 \mathrm{~mL}$ SPME vials which were sealed with PTFE/Silicon septum (Supelco). The samples were extracted by SPME fiber of $2 \mathrm{~cm}$ length (DVB/CAR/PDMS, Supelco. Bellefonte, PA, USA) before being analyzed by GC-MS. The extraction and chromatography conditions were described in Rodríguez-Bencomo et al. (2011). The analyses were performed in duplicate.

The odour activity value (OAV) of a volatile compound was calculated as $\mathrm{OAV}=$ compound concentration/compound odour threshold, and expressed as aroma units (a.u.). Odour threshold data were taken from the bibliography (Zea et al., 2001; Culleré et al., 2004; Escudero et al., 2004; 2007). The OAV was also calculated for each family and for the total volatile composition as the sum of the OAV values of individual compounds and families, respectively.

To determine the per se contribution of the extracts to the volatile composition of the wines, solutions of the extracts $(2 \mathrm{~g} / \mathrm{L})$ in synthetic wine $(12 \%$ ethanol, $3.5 \mathrm{~g} / \mathrm{L}$ tartaric acid; $\mathrm{pH} 3.5)$ were prepared and subjected to volatile compound analysis.

\subsection{Determination of Total Phenolic Content}

The total phenolic content of the wines used was determined by the method of Singleton \& Rossi (1965). The results were expressed as mg of gallic acid equivalents per liter of wine. Analyses were carried out in triplicate. 


\subsection{Phenolic Compound Analysis}

The analysis of non-anthocyanin phenolic compounds was conducted according to Monagas et al. (2005) and further described in (García-Ruiz et al., 2012). Analysis was carried out in duplicate.

The dose-over-taste factor (DoT) of several phenolic acids (protocatechuic, caffeic, cis- and trans-caftaric and trans-coutaric acids), flavan-3-ols (catechin and epicatechin) and flavonols (quercetin-3-O-glucoside) was calculated following the formula DoT = compound concentration/compound sensory threshold, and expressed as astringency units (as.u). Sensory threshold data were taken from the bibliography (Hufnagel \& Hofmann, 2008; Sáenz-Navajas et al., 2012).

In order to determine the per se contribution of the extracts to the phenolic composition of the wines, solutions of the extracts $(2 \mathrm{~g} / \mathrm{L})$ in synthetic wine $(12 \%$ ethanol, $3.5 \mathrm{~g} / \mathrm{L}$ tartaric acid; $\mathrm{pH}$ 3.5) were prepared and subjected to phenolic compounds analysis.

\subsection{Statistical Analysis}

The statistical methods used for data analysis were: one-way Analysis of Variance (ANOVA) to test the effect of the treatment factor on the concentration of studied compounds and Least Significant Difference (LSD) test for comparison of means; and Principal Component Analysis (PCA), from correlation matrix, to examine the relationships between analyzed variables and samples. STATISTICA program version 7.1 (StatSoft, Inc. 2005, www.statsoft.com) was used for data processing.

\section{Results and Discussion}

\subsection{Volatile Compounds}

Table 1 reports the concentration of the different volatile compounds $(n=36)$ determined in the Chardonnay wines before and after MLF, in absence and presence of the two phenolic extracts (eucalyptus and almond): esters $(n=15)$, alcohols $(n=5)$, terpenes $(n=4), C 13$ nor-isoprenoids $(n=2)$, volatile phenols $(n=6)$, acids $(n=3)$ and lactones $(n=1)$. The process of MLF itself produced significant variations in the volatile composition of the Chardonnay wine. In general, the concentration of esters, alcohols and volatile phenols were significantly lower $(p<0.05)$ in the wine after MLF (control wine) in comparison to the wine before MLF. This was particularly noticeable for the ethyl esters of butyric, hexanoic, decanoic and dodecanoic acids and for acetates of isobutyl, isoamyl and hexyl alcohols (> 80\% reduction in comparison to the wine before MLF). Other compounds showing lower concentration in the wines after MLF were nerol, $\alpha$-ionone and hexanoic acid. On the other hand, ethyl lactate showed higher concentration in the wines after MLF (over 6.5), which was associated to the production of lactic acid during MLF. Other compounds such as linalool, $\beta$-citronellol, $\beta$-damascenone, benzyl alcohol and $\gamma$-nonalactone also showed higher concentrations in the wine after MLF. These changes could be associated to the action of LAB and/or to different chemical reactions (i.e., acid catalyzed hydrolysis) that occur during the MLF process (Ugliano et al., 2003; Hernández-Orte et al., 2009; Gagné et al., 2011). 
The first difference observed in the volatile composition between extract-treated and control wines is that, in general, the wines elaborated with both antimicrobial extracts (from eucalyptus leaves and almond skins) showed a significant $(\mathrm{p}<0.05)$ higher content of esters (Table 1$)$. This was particularly noticeable for ethyl butyrate, isoamyl acetate, hexyl acetate and $\beta$-phenylethyl acetate for both extract-treated wines, and for isobutyl acetate for the wine treated with the eucalyptus extract, and for ethyl lactate for the wine treated with the almond extract. Only diethyl succinate showed significant higher content in the control wines that in wines treated with antimicrobial extracts. These changes in the concentration of esters were explained in terms of the capacity of plant extracts to influence the growth and/or metabolism of LAB, promoting, for example, an enhancement in the bacterial production of succinic acid and hence a higher concentration of diethyl succinate.

The wines treated with the antimicrobial extracts also showed significant higher content of lactones ( $\gamma$-nonalactone) for both eucalyptus and almond extracts, and of terpenes ( $\alpha$-terpineol and nerol) and volatile phenols (4-ethylguaiacol, eugenol, 4-ethylphenol, 2-methoxy-4-vinylphenol and 2,6-dimethoxyphenol) in the case of the wines treated with the eucalyptus extract. Analysis of the extract solutions in synthetic wine $(2 \mathrm{~g} / \mathrm{L})$ revealed that the eucalyptus extract itself contained some terpenes and volatile phenols, which could explain, at least partially, the higher content of these compounds in the wines treated with this extract.

On the other hand, significant lower content in the wines treated with the antimicrobial phenolic extracts in comparison to the control wine, were observed for $\beta$-citronellol, $\beta$-damascenone, benzyl alcohol and $\beta$-phenylethanol. These facts could be related with the enzymatic hydrolysis of glycosidic aroma precursors and the inhibition of the enzymatic activities of LAB by the phenolic extracts (Ugliano et al., 2003; Hernández-Orte et al., 2009).

Table 1. Volatile composition of wines before and after malolactic fermentation (MLF).

\begin{tabular}{|l|c|c|c|c|c|}
\hline & \multirow{2}{*}{ Before MLF } & \multicolumn{3}{|c|}{ After MLF } & Odor \\
\cline { 4 - 6 } & & Control & +Eucalyptus & +Almond & thresholds \\
\hline & & & extract & extract & \\
\hline Esters & & & & & \\
\hline Ethyl butyrate & $770 \pm 68$ & $* 34.3 \mathrm{a} \pm 5.8$ & $* 59.1 \mathrm{~b} \pm 1.8$ & $* 71.3 \mathrm{~b} \pm 6.1$ & 20 \\
\hline Ethyl 2-methylbutyrate & $28.6 \pm 1.8$ & $* 18.6 \pm 0.7$ & $24.1 \pm 4.4$ & $23.9 \pm 1.9$ & 18 \\
\hline Ethyl hexanoate & $2332 \pm 78$ & $* 337 \pm 14$ & $* 401 \pm 106$ & $* 388 \pm 65$ & 14 \\
\hline Ethyl octanoate $(\mathrm{mg} / \mathrm{L})$ & $5.75 \pm 0.11$ & $* 1.63 \pm 0.21$ & $* 1.82 \pm 0.12$ & $* 2.11 \pm 0.36$ & 0.005 \\
\hline Ethyl decanoate $(\mathrm{mg} / \mathrm{L})$ & $14.8 \pm 0.2$ & $* 1.64 \pm 0.28$ & $* 1.48 \pm 0.11$ & $* 1.92 \pm 0.09$ & 0.200 \\
\hline Diethyl succinate & $102 \pm 36$ & $147 \mathrm{~b} \pm 7$ & $114 \mathrm{a} \pm 3$ & $138 \mathrm{~b} \pm 2$ & 200000 \\
\hline Ethyl dodecanoate & $2630 \pm 90$ & $* 430 \mathrm{a} \pm 30$ & $* 410 \mathrm{a} \pm 30$ & $* 520 \mathrm{~b} \pm 1$ & 500 \\
\hline Ethyl cinnamate & $13.1 \pm 0.1$ & $13.4 \pm 0.1$ & $13.4 \pm 0.1$ & $13.3 \pm 0.1$ & 1.1 \\
\hline Ethyl lactate $(\mathrm{mg} / \mathrm{L})$ & $5.84 \pm 0.72$ & $* 39.6 \mathrm{a} \pm 2.3$ & $* 41.6 \mathrm{a} \pm 5.3$ & $* 67.8 \mathrm{~b} \pm 2.9$ & 154 \\
\hline Ethyl acetate $(\mathrm{mg} / \mathrm{L})$ & $110 \pm 14$ & $* 14.4 \mathrm{a} \pm 1.5$ & $* 23.9 \mathrm{~b} \pm 0.9$ & $* 20.8 \mathrm{~b} \pm 0.1$ & 12.3 \\
\hline Isobutyl acetate & $122 \pm 8$ & $* 5.51 \mathrm{a} \pm 2.07$ & $* 16.5 \mathrm{~b} \pm 2.6$ & $* 3.72 \mathrm{a} \pm 0.16$ & 1600 \\
\hline Butyl acetate & $18.5 \pm 0.9$ & $* 7.90 \pm 3.40$ & $* 5.00 \pm 0.10$ & $* 5.10 \pm 0.10$ & 1800 \\
\hline Isoamyl acetate & $7230 \pm 120$ & $* 50 \mathrm{a} \pm 10$ & $* 160 \mathrm{~b} \pm 30$ & $* 230 \mathrm{~b} \pm 30$ & 30 \\
\hline Hexyl acetate & $633 \pm 2$ & $* \operatorname{tr}$ & $* 8.14 \mathrm{a} \pm 2.44$ & $* 16.4 \mathrm{~b} \pm 2.5$ & 1500 \\
\hline$\beta$-Phenylethyl acetate & $322 \pm 2$ & $* 131 \mathrm{a} \pm 11$ & $* 235 \mathrm{~b} \pm 1$ & $* 282 \mathrm{c} \pm 7$ & 1100 \\
\hline Terpenes & & & & & \\
\hline
\end{tabular}




\begin{tabular}{|l|c|c|c|c|c|}
\hline Linalool & $4.74 \pm 0.58$ & $* 7.06 \pm 0.07$ & $6.68 \pm 0.96$ & $* 6.58 \pm 0.26$ & 25 \\
\hline$\alpha$-Terpineol & $\operatorname{tr}$ & $\operatorname{tr}$ & $* 6.04 \pm 1.38$ & $\operatorname{tr}$ & 250 \\
\hline$\beta$-Citronellol & $2.89 \pm 0.54$ & $* 6.15 \mathrm{~b} \pm 0.32$ & $* 4.86 \mathrm{a} \pm 0.25$ & $* 4.95 \mathrm{a} \pm 0.42$ & 100 \\
\hline Nerol & $3.98 \pm 0.27$ & $* \operatorname{tr}$ & $* 1.97 \mathrm{~b} \pm 0.01$ & $* \operatorname{tr}$ & 300 \\
\hline C13 nor-Isoprenoids & & & & & \\
\hline$\beta$-Damascenone & $7.10 \pm 1.17$ & $* 11.5 \mathrm{~b} \pm 0.2$ & $* 9.76 \mathrm{a} \pm 0.29$ & $10.6 \mathrm{a} \pm 0.1$ & 0.05 \\
\hline$\alpha$-Ionone & $37.9 \pm 4.1$ & $* 15.4 \pm 1.5$ & $* 13.2 \pm 1.2$ & $* 15.1 \pm 1.6$ & 2.6 \\
\hline Alcohols & & & & & \\
\hline 1-Hexanol & $1180 \pm 20$ & $* 710 \pm 10$ & $* 750 \pm 30$ & $* 780 \pm 20$ & 8000 \\
\hline trans-3-Hexen-1-ol & $64.9 \pm 1.7$ & $* 47.9 \pm 1.0$ & $* 52.3 \pm 3.3$ & $* 54.1 \pm 3.0$ & 1000 \\
\hline cis-3-Hexen-1-ol & $148 \pm 11$ & $* 101 \pm 1$ & $* 104 \pm 6$ & $* 107 \pm 3$ & 400 \\
\hline Benzyl alcohol & $53.4 \pm 4.5$ & $* 155 \mathrm{~b} \pm 3$ & $* 125 \mathrm{a} \pm 3$ & $* 116 \mathrm{a} \pm 3$ & 200000 \\
\hline$\beta$-Phenylethanol (mg/L) & $23.1 \pm 3.0$ & $19.2 \mathrm{~b} \pm 0.5$ & $* 17.3 \mathrm{a} \pm 0.3$ & $* 17.9 \mathrm{a} \pm 0.2$ & 14 \\
\hline Acids & & & & & \\
\hline Hexanoic acid (mg/L) & $30.6 \pm 3.6$ & $* 9.36 \mathrm{ab} \pm 0.82$ & $* 8.14 \mathrm{a} \pm 0.15$ & $* 10.3 \mathrm{~b} \pm 0.4$ & 0.420 \\
\hline Octanoic acid (mg/L) & $9.07 \pm 0.89$ & $8.20 \pm 0.50$ & $8.07 \pm 0.48$ & $8.55 \pm 0.07$ & 0.500 \\
\hline Decanoic acid (mg/L) & $0.81 \pm 0.09$ & $* 2.40 \pm 0.30$ & $* 2.57 \pm 0.27$ & $* 2.71 \pm 0.01$ & 1 \\
\hline Lactones & & & & & \\
\hline$\gamma$-Nonalactone & $4.25 \pm 0.46$ & $* 5.96 \mathrm{a} \pm 0.15$ & $* 9.26 \mathrm{~b} \pm 0.43$ & $* 13.6 \mathrm{c} \pm 0.3$ & 30 \\
\hline Volatile phenols & & & & & \\
\hline 4-Ethylguaiacol & $1.53 \pm 0.06$ & $* 1.30 \mathrm{a} \pm 0.03$ & $* 1.65 \mathrm{~b} \pm 0.05$ & $* 1.32 \mathrm{a} \pm 0.01$ & 33 \\
\hline Eugenol & $19.5 \pm 0.1$ & $19.4 \mathrm{a} \pm 0.2$ & $* 31.3 \mathrm{c} \pm 0.1$ & $19.7 \mathrm{~b} \pm 0.2$ & 6 \\
\hline 4-Ethylphenol & $9.03 \pm 0.22$ & $* 8.48 \mathrm{a} \pm 0.04$ & $* 29.8 \mathrm{~b} \pm 2.7$ & $* 8.32 \mathrm{a} \pm 0.01$ & 440 \\
\hline 2-methoxy-4-vinylphenol & $1026 \pm 24$ & $588 \pm 81$ & $* 610 \pm 3$ & $733 \pm 27$ & 2.8 \\
\hline 2,6-Dimethoxyphenol & $36.2 \pm 0.9$ & $38.0 \mathrm{a} \pm 1.2$ & $* 87.3 \mathrm{~b} \pm 3.0$ & $40.8 \mathrm{a} \pm 4.9$ & 570 \\
\hline 4-Vinylphenol & $907 \pm 26$ & $* 633 \pm 12$ & $* 614 \pm 64$ & $* 532 \pm 24$ & 180 \\
\hline
\end{tabular}

Concentration values in $\mu \mathrm{g} / \mathrm{L}$ except indicated.

Odour threshold values in $\mu \mathrm{g} / \mathrm{L}$ except indicated. tr=traces

* on the left indicates significant differences in time during MLF $(\mathrm{p}<0.05)$.

a-c Mean values with different letter on the right indicate statistically significant differences among the three wines (control and with eucalyptus or almond extracts) $(\mathrm{p}<0.05)$.

\subsection{Phenolic Compounds}

Results of total phenolic content (Folin-Ciocalteu) and concentrations of individual phenolic compounds in Chardonnay wines are showed in the Table 2. With regard to the total phenolic content, the wines treated with the antimicrobial extracts showed significantly $(\mathrm{p}<0.05)$ higher value (340 and $411 \mathrm{mg} / \mathrm{L}$, respectively, for the eucalyptus and almond extracts) than the control wine $(238 \mathrm{mg} / \mathrm{L})$. These results were consistent with the content of total polyphenols in the antimicrobial extracts per se (see Materials and Methods); their addition ( $2 \mathrm{~g} / \mathrm{L}$ ) to the wine would lead to a theoretical contribution of 178 and $330 \mathrm{mg} / \mathrm{L}$ of total polyphenols, respectively, for the eucalyptus and almond extracts.

A total of 13 phenolic compounds were quantified in the wines before and after MLF, which were classified into phenolic families: hydroxybenzoic acids and esters $(n=2)$, hydroxycinnamic acids and esters $(n=6)$, phenolic alcohol $(n=1)$, flavan-3-ols $(n=2)$ and flavonols ( $n=2)$ (Table 2). After MLF, the control wine showed a significant higher content for hydroxybenzoic and hydroxycinnamic acids (except for caffeic acid) than the wine before 


\section{$\triangle$ Macrothink}

MLF. Opposite behaviour was observed for alcohols (tyrosol) and flavan-3-ols, whose content was lower after MLF. In relation to flavonols, the MLF seemed to involve the hydrolysis of quercetin-3-O-glucoside (higher content before MLF) into quercetin (higher content after MLF). These results agreed with previous studies about the transformations of phenolic compounds during MLF in red wines (Hernández et al., 2007).

Addition of the eucalyptus extract led to some changes in the concentration of phenolic individual compounds, although no general trend was observed. Of relevance was the high content of quercetin-3-O-glucoside found in these wines $(5.20 \mathrm{mg} / \mathrm{L})$, in comparison to the control. Moreover, it was detected by MALDI-TOF that the eucalyptus extract contained quercetin-3-O-glucoside, among other phenolic compounds (data not shown), which might explained the results found. The wines treated with the almond extract showed, in general, a higher content for most of the individual compounds in comparison to the control, especially for (+)-catechin $(12.5 \mathrm{mg} / \mathrm{L})$ and (-)-epicatechin $(3.65 \mathrm{mg} / \mathrm{L})$. This was also attributed to the almond extract per se, as almond skins have been reported to be rich in flavan-3-ols (Garrido et al., 2008).

Table 2. Phenolic composition of wines before and after malolactic fermentation (MLF).

\begin{tabular}{|c|c|c|c|c|c|}
\hline & Before MLF & & After MLF & & ${ }^{1}$ Sensory \\
\hline & & Control & +Eucalyptus & +Almond & thresholds \\
\hline & & & extract & extract & \\
\hline${ }^{\mathrm{a} T o t a l}$ Polyphenols & $227 \pm 1$ & $* 238 \mathrm{a} \pm 2$ & $* 340 \mathrm{~b} \pm 3$ & $* 411 \mathrm{c} \pm 1$ & \\
\hline \multicolumn{6}{|c|}{ Hydroxybenzoic acids and esters } \\
\hline Protocatechuic acid & $2.77 \pm 0.01$ & $* 3.80 \mathrm{~b} \pm 0.03$ & $* 4.93 \mathrm{c} \pm 0.17$ & $* 3.38 \mathrm{a} \pm 0.02$ & 32 \\
\hline Ethyl gallate & $5.37 \pm 0.03$ & $* 6.99 \mathrm{~b} \pm 0.03$ & $* 6.03 \mathrm{a} \pm 0.07$ & $* 6.24 \mathrm{a} \pm 0.11$ & \\
\hline \multicolumn{6}{|c|}{ Hydroxycinnamic acids and esters } \\
\hline Caffeic acid & $1.68 \pm 0.05$ & $* 1.41 \mathrm{a} \pm 0.06$ & $* 3.67 \mathrm{c} \pm 0.11$ & $* 1.91 \mathrm{~b} \pm 0.09$ & 13 \\
\hline Caffeic acid derivate & $0.77 \pm 0.01$ & $* 1.11 \mathrm{c} \pm 0.01$ & $* 0.87 \mathrm{~b} \pm 0.01$ & $* 0.72 \mathrm{a} \pm 0.01$ & \\
\hline cis-Caftaric acid & $3.94 \pm 0.14$ & $3.95 b \pm 0.32$ & $3.81 \mathrm{~b} \pm 0.19$ & $* 2.94 \mathrm{a} \pm 0.03$ & 5 \\
\hline trans-Caftaric acid & $7.23 \pm 0.04$ & $* 8.65 \mathrm{a} \pm 0.03$ & $* 8.52 \mathrm{a} \pm 0.01$ & $* 9.14 \mathrm{~b} \pm 0.11$ & 5 \\
\hline cis-Coutaric acid & $3.09 \pm 0.08$ & $* 3.54 \pm 0.04$ & $* 3.65 \pm 0.02$ & $* 3.67 \pm 0.11$ & \\
\hline trans-Coutaric acid & $1.34 \pm 0.03$ & $* 1.64 \mathrm{a} \pm 0.03$ & $* 1.76 \mathrm{ab} \pm 0.05$ & $* 1.77 \mathrm{~b} \pm 0.05$ & 10 \\
\hline \multicolumn{6}{|l|}{ Phenolic alcohol } \\
\hline Tyrosol & $14.2 \pm 0.4$ & $* 12.1 \mathrm{a} \pm 0.1$ & $* 12.6 \mathrm{ab} \pm 0.5$ & $* 13.6 \mathrm{~b} \pm 0.4$ & \\
\hline \multicolumn{6}{|l|}{ Flavan-3-ols } \\
\hline (+)-Catechin & $4.81 \pm 0.06$ & $* 4.24 \mathrm{a} \pm 0.04$ & $* 6.55 b \pm 0.03$ & $* 12.5 c \pm 0.3$ & 119 \\
\hline (-)-Epicatechin & $2.13 \pm 0.05$ & $* 1.33 \mathrm{a} \pm 0.02$ & $* 1.53 \mathrm{a} \pm 0.10$ & $* 3.65 b \pm 0.10$ & 270 \\
\hline \multicolumn{6}{|l|}{ Flavanols } \\
\hline Quercetin & $11.7 \pm 0.1$ & $12.0 \mathrm{~b} \pm 0.3$ & $* 11.4 \mathrm{a} \pm 0.1$ & $* 12.2 \mathrm{~b} \pm 0.1$ & 10 \\
\hline Quercetin-3-O-glucoside & $1.86 \pm 0.03$ & $* 1.16 \mathrm{a} \pm 0.01$ & $* 5.20 \mathrm{c} \pm 0.05$ & $* 2.93 b \pm 0.07$ & 0.3 \\
\hline
\end{tabular}

Concentration values in $\mathrm{mg} / \mathrm{L}$.

a Total polyhenols were expressed as mg of gallic acid equivalents per liter of wine.

* on the left indicates significant differences in time during MLF $(\mathrm{p}<0.05)$

a-c Mean values with different letter on the right indicate statistically significant differences among the three wines (control 
and with eucalyptus or almond extracts) $(\mathrm{p}<0.05)$.

\subsection{Theorical Calculation of Sensory Impact}

As an approach to evaluating the impact on the organoleptic properties of the Chardonnay wine due to the changes in its volatile and phenolic compounds observed after treatment with antimicrobial extracts, we calculated the OAV for the volatile compounds and the DoT for phenolic compounds (Table 3). Only 19 of the 36 volatile compounds quantified in these wines were found to have an OAV >1; this is to say, their concentrations in these wines were higher than their corresponding odour thresholds.

\subsection{Comparison among Treatments: Statistical Multivariate Analysis}

Principal Component Analysis (PCA) was applied to better visualize the effect of the addition of antimicrobial phenolic extracts on volatile and phenolic composition of the Chardonnay wines. Only the compounds with OAV and DoT values $>1$ (see Table 3) were included in this analysis. The first principal component (PC1) explained $74.6 \%$ of data variation and presented higher correlation values with ethyl acetate (-0.981), ethyl butyrate (-0.990), isoamyl acetate $(-0.998)$, ethyl hexanoate $(-0.997)$, ethyl octanoate (-0.995), ethyl decanoate $(-0.998)$, $\beta$-damascenone (0.881), $\alpha$-ionone (-0.989), hexanoic acid (-0.995), ethyl dodecanoate $(-0.999)$, $\beta$-phenylethyl alcohol (-0.878), ethyl cinnamate (0.870), 2-methoxy-4-vinylphenol (-0.954), decanoic acid (0.961), 4-vinylphenol (-0.925) and trans-caftaric acid (0.923). The PC2 explained $13.9 \%$ of the data variation and presented higher correlation values with eugenol (0.905), quercetin (-0.858) and quercetin-3-O-glucoside (0.898). Figure 1 shows the representation of the samples in the plane defined by the PC1 and PC2 which explained $88.5 \%$ of data variation. PC1 showed high and negative values for the wine before MLF while all wines after MLF showed positive and similar values for this PC. Therefore, PC1 is mainly showing a separation among wines because of the differences in the composition before and after of MLF, but not due to the type of treatment applied. This result is reflected in the high values of esters, principal volatile family that changes during MLF. On the other hand, PC2 showed positive values for wines treated with eucalyptus extract, values slight lower than cero for wines added from almond extract and finally, negative values for control wines. PC2 is showing a separation among wines for the type of treatment which could be related with the higher concentration of eugenol and quercetin-3-O-glucoside in the wines treated with eucalyptus extract. 
Table 3. Odour Activity and Dose-over-Threshold values of family of volatile and phenolic compounds, respectively, of wines before and after malolactic fermentation (MLF).

\begin{tabular}{|c|c|c|c|c|c|}
\hline & Before MLF & & After MLF & & \\
\hline & & Control & +Eucalyptus & +Almond & \\
\hline & & & extract & extract & \\
\hline \multicolumn{5}{|c|}{ Odor Activity Value (OAV)(a.u.) } & \multirow[t]{2}{*}{ Sensory Note } \\
\hline \multicolumn{5}{|l|}{ Esters } & \\
\hline Ethyl butyrate & 38.5 & 1.71 & 2.95 & 3.57 & Fruity \\
\hline Ethyl 2-methylbutyrate & 1.59 & 1.03 & 1.34 & 1.33 & Fruity \\
\hline Ethyl hexanoate & 167 & 24.1 & 28.7 & 27.7 & Fruity \\
\hline Ethyl octanoate & 1150 & 326 & 364 & 421 & Fruity \\
\hline Ethyl decanoate & 73.8 & 8.18 & 7.39 & 9.60 & Fruity, grape \\
\hline Ethyl dodecanoate & 5.25 & 0.851 & 0.827 & 1.04 & Leaf \\
\hline Ethyl cinnamate & 13.1 & 13.4 & 13.4 & 13.3 & Flowery, sweet \\
\hline Ethyl acetate & 8.94 & 1.17 & 1.94 & 1.69 & Pineapple \\
\hline Isoamyl acetate & 241 & 1.62 & 5.29 & 7.7 & Fruity, banana \\
\hline$\beta$-Phenylethyl acetate & 1.29 & 0.523 & 0.938 & 1.13 & Flowery \\
\hline \multicolumn{6}{|l|}{ C13 nor-isoprenoids } \\
\hline$\beta$-Damascenone & 142 & 229 & 195 & 211 & Baked apple \\
\hline$\alpha$-Ionone & 14.6 & 5.93 & 5.08 & 5.82 & Wood, violet \\
\hline \multicolumn{6}{|l|}{ Alcohols } \\
\hline$\beta$-Phenylethanol & 1.65 & 1.37 & 1.24 & 1.28 & Roses \\
\hline \multicolumn{6}{|l|}{ Acids } \\
\hline Hexanoic acid & 72.7 & 22.3 & 19.4 & 24.6 & Sweat \\
\hline Octanoic acid & 18.1 & 16.4 & 16.1 & 17.1 & Fatty, cheese \\
\hline Decanoic acid & 0.811 & 2.4 & 2.57 & 2.71 & Fatty, rancid \\
\hline \multicolumn{6}{|l|}{ Volatile Phenols } \\
\hline 2-methoxy-4-vinylphenol & 25.6 & 14.7 & 15.2 & 18.3 & Phenolic, smokey \\
\hline 4-Vinylphenol & 5.04 & 3.52 & 3.41 & 2.95 & Almond shell \\
\hline Eugenol & 3.26 & 3.23 & 5.21 & 3.29 & Clove, honey \\
\hline \multicolumn{5}{|c|}{ Dose-Over-Threshold (DoT) (as.u.) } & Astringent Note \\
\hline \multicolumn{6}{|c|}{ Hydroxycinnamic acids and esters } \\
\hline trans-Caftaric acid & 1.45 & 1.73 & 1.70 & 1.83 & Puckering \\
\hline \multicolumn{6}{|l|}{ Flavonols } \\
\hline Quercetin & 1.17 & 1.20 & 1.14 & 1.22 & Velvety \\
\hline Quercetin-3-O-glucoside & 6.20 & 3.76 & 17.3 & 9.77 & Velvety \\
\hline
\end{tabular}




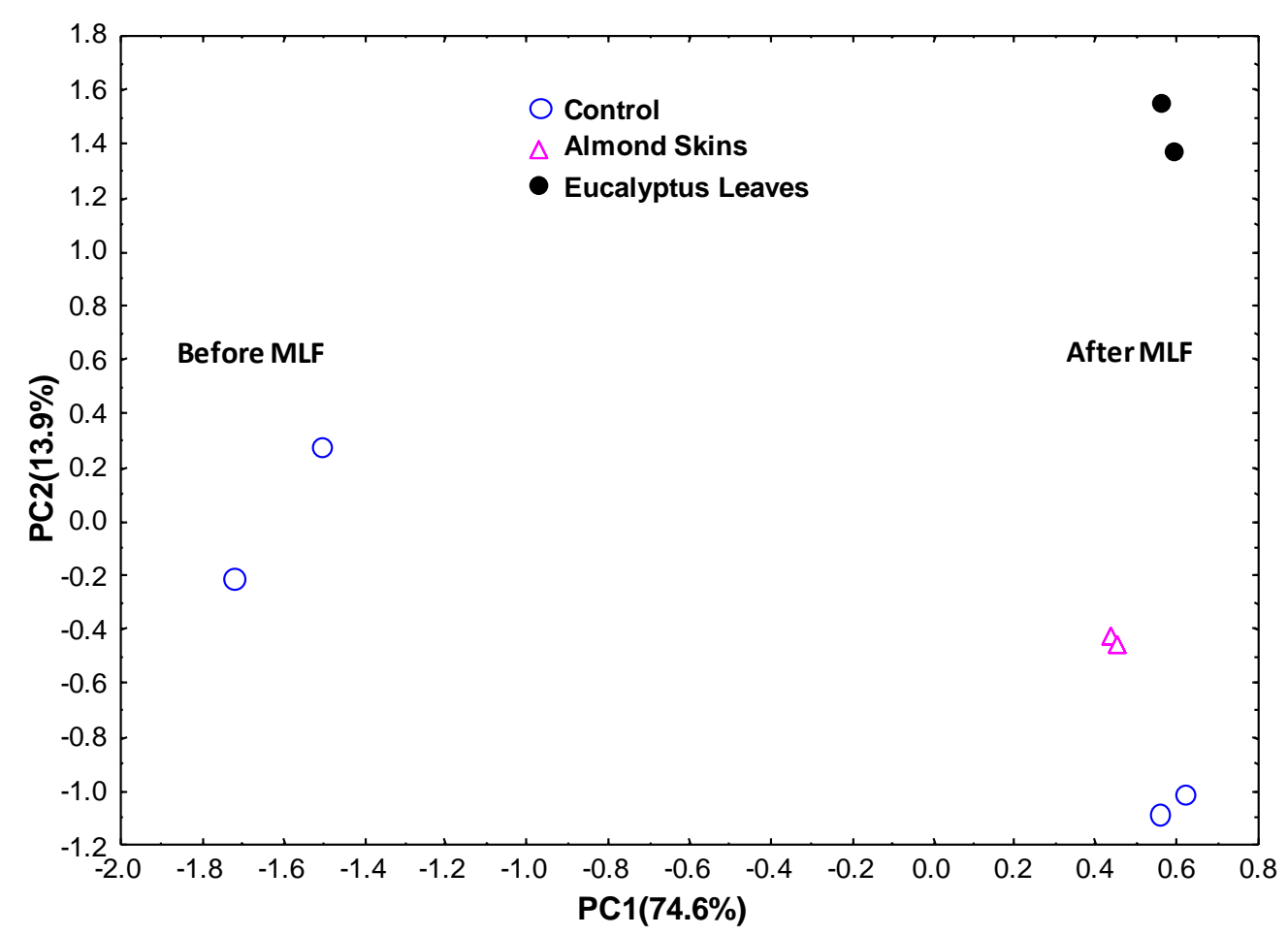

Figure 1. Distribution of wines studied in the plane defined by principal components 1 and 2 obtained from the principal component analysis.

\section{Conclusion}

In summary, this paper confirms some changes on the volatile and phenolic composition of a Chardonnay wine after addition of two commercial antimicrobial phenolic extracts (from eucalyptus leaves and almond skins) before MLF. Addition of both extracts led to statistically significant changes $(\mathrm{p}<0.05)$ in the concentration of different volatile and phenolic compounds. However, taking in mind the theoretical calculations for OAV and DoT, we can conclude that only changes in very few compounds would affect wine organoleptic properties (i.e. aroma and astringency) as their OAV and DoT values were > 1: ethyl butyrate, ethyl acetate, isoamyl acetate, $\beta$-phenylethyl acetate, $\beta$-damascenone and quercetin-3- $O$-glucoside for wines treated with both extracts, eugenol and quercetin for wines treated only with the eucalyptus extract, and ethyl dodecanoate and trans-caftaric acid for wines treated with the almond extract. Therefore, these results confirm the potential application of phenolic extracts as alternative to SO2 during MLF of white wines such as Chardonnay. But in any case, further trials involving the addition of antimicrobial extracts to white wines during MLF will be performed at winery scale, and will include sensory analysis.

\section{Acknowledgements}

This work has been funded by the Spanish Ministry for Science and Innovation (AGL2006-04514, AGL2009-13361-C02-00 and CSD2007-00063 Consolider Ingenio 2010 FUN-C-FOOD Projects), and the Comunidad de Madrid (ALIBIRD P2009/AGR-1469 Project). JJRB and AGR are the recipients of a fellowship from the JAE-Doc Program (CSIC) and DANONE Institute, respectively. The authors would like to thank the Bodegas Miguel Torres S. 
A. winery for their collaboration and Biosearch Life S.A. by the phenolic extracts supplied.

\section{References}

Abee, T., Krockel, L.,\& Hill, C. (1995). Bacteriocins: modes of action and potentials in food preservation and control of food poisoning. International Journal of Food Microbiology, 28, 169-185. http://dx.doi.org/10.1016/0168-1605(95)00055-0

Bartolomé, B., García-Ruiz, A., Cueva, C., González-Rompinelli, E., Rodríguez-Bencomo, J. J., Sánchez-Patán, F., Martín-Álvarez, P. J., \& Moreno-Arribas, M. V. (2011). Publication date: 29-12-2011. Winemaking procedure that comprises adding a plant phenolic extract with antimicrobial properties against lactic acid and /or acetic bacteria. Spanish Patent Application no. P201132134.

Bartowsky, E. J. (2009). Bacterial spoilage of wine and approaches to minimize it. Letters in Applied Microbiology, 48, 149-156. http://dx.doi.org/10.1111/j.1472-765X.2008.02505.x

Bauer R., \& Dicks L. M. T., 2004. Control of malolactic fermentation in wine. A Review. South African Journal for Enology and Viticulture, 25, 74-88.

Culleré, L., Escudero A., Cacho J., \& Ferreira V. (2004). Gas chromatography-olfactometry and chemical quantitative study of the aroma of six premium quality spanish aged red wines. Journal of Agricultural and Food Chemistry, 52, 1653-1660. http://dx.doi.org/10.1021/jf0350820

Escudero, A., Campo E., Fariña L., Cacho J., \& Ferreira V. (2007). Analytical characterization of the aroma of five premium red wines. Insights into the role of odor families and the concept of fruitiness of wines. Journal of Agricultural and Food Chemistry, 55, 4501-4510. http://dx.doi.org/10.1021/jf0636418

Escudero, A., Gogorza, B., Melus M. A., Ortín, N., Cacho, J., \& Ferreira V. (2004). Characterization of the aroma of a wine from Maccabeo. Key role played by compounds with low odor activity values. Journal of Agricultural and Food Chemistry. 52, 3516-3524. http://dx.doi.org/10.1021/jf0353411

Gagné, S., Lucas, P. M., Perello, M. C., Claisse, O., Lonvaud-Funel, A., \& de Revel, G. (2011). Variety and variability of glycosidase activities in an Oenococcus oeni strain collection tested with synthetic and natural substrates. Journal of Applied Microbiology, 110, 218-228. http://dx.doi.org/10.1111/j.1365-2672.2010.04878.x

García-Ruiz A., Cueva C., González-Rompinelli E. M., Yuste M., Torres M., Martín-Álvarez P.J., Bartolomé, B., \& Moreno-Arribas M.V. (2012). Antimicrobial phenolic extracts able to inhibit lactic acid bacteria growth and wine malolactic fermentation. Food Control, 28, 212-219. http://dx.doi.org/10.1016/j.foodcont.2012.05.002

García-Ruiz, A., Bartolomé, B., Cueva C., Martín-Álvarez P. J., \& Moreno-Arribas M. V. (2009). Inactivation of oenological lactic acid bacteria (Lactobacillus hilgardii and Pediococcus pentosaceus) by wine phenolic compounds. Journal of Applied Microbiology, 107, 1042-1053. http://dx.doi.org/10.1111/j.1365-2672.2009.04287.x 
García-Ruiz, A., Moreno-Arribas M. V., Martín-Álvarez P. J., \& Bartolomé B. (2011). Comparative study of the inhibitory effects of wine polyphenols on the growth of enological lactic acid bacteria. International Journal of Food Microbiology, 145, 426-431. http://dx.doi.org/10.1016/j.ijfoodmicro.2011.01.016

García-Ruiz, A., Rodríguez-Bencomo, J. J., Garrido, I. Martín-Álvarez, P. J., Moreno-Arribas M. V., \& Bartolomé B. (2013). Assessment of the impact of the addition of antimicrobial plant extracts to wine. Volatile and phenolic composition. Journal of the Science of Food and Agriculture, 93, 2507-2516. http://dx.doi.org/10.1002/jsfa.6067

Garrido, I., Monagas, M., Gómez-Cordovés, C., \& Bartolomé, B. (2008). Polyphenols and antioxidant properties of almond skins: Influence of industrial processing. Journal of Food Science, 73, C106-C115. http://dx.doi.org/10.1111/j.1750-3841.2007.00637.x

Hernández, T., Estrella, I., Pérez-Gordo, M., Alegría, E. G., Tenorio, C., Ruiz-Larrrea, F., \& Moreno-Arribas, M. V. (2007). Contribution of malolactic fermentation by Oenococcus oeni and Lactobacillus plantarum to the changes in the nonanthocyanin polyphenolic composition of red wine. Journal of Agricultural and Food Chemistry, 55, 5260-5266. http://dx.doi.org/10.1021/jf063638o

Hernández-Orte, P., Cersosimo, M., Loscos, N., Cacho, J., Garcia-Moruno, E., \& Ferreira, V. (2009). Aroma development from non-floral grape precursors by wine lactic acid bacteria. Food Research International, 42, 773-781. http://dx.doi.org/10.1016/j.foodres.2009.02.023

Hufnagel, J. C., \& Hofmann, T. (2008). Orosensory-directed identification of astringent mouthfeel and bitter-tasting compounds in red wine. Journal of Agricultural and Food Chemistry, 56, 1376-1386. http://dx.doi.org/10.1021/jf073031n

Lerm, E., Engelbrecht, L., \& du Toit., M. (2010). Malolactic Fermentation: The ABC's of MLF. South African Journal of Enology and Viticulture, 31, 186-212.

Matthews, A., Grimaldi, A., Walker, M., Bartowsky, E., Grbin, P., \& Jiranek V. (2004). Lactic acid bacteria as a potential source of enzymes for use in vinification. Applied and Environmental Microbiology, $\quad 70, \quad 5715-5731$. http://dx.doi.org/10.1128/AEM.70.10.5715-5731.2004

Monagas, M., Bartolomé, B., \& Gómez-Cordovés, C. (2005). Evolution of polyphenols in red wines from Vitis vinífera L. during aging in the bottle. I. Anthocyanins and pyroanthocyanins. European Food Research and Technology, 220, 607-614. http://dx.doi.org/10.1007/s00217-004-1108-x

Pozo-Bayón, M. A, Alegría E. G, Polo, M. C., Tenorio, C., Martín-Álvarez, P. J., Calvo de la Banda, M. T., Ruiz-Larrrea, F., \& Moreno-Arribas, M. V (2005). Wine volatile and amino acid composition after malolactic fermentation: effect of Oenococcus oeni and Lactobacillus plantarum starter cultures. Journal of Agricultural and Food Chemistry, 53, 8729-8735. http://dx.doi.org/10.1021/jf050739y

Reguant, C., Bordons, A., Arola, L., \& Rozes, N. (2000). Influence of phenolic compounds on 


\section{Macrothink}

Journal of Agricultural Studies

ISSN 2166-0379

2014, Vol. 2, No. 2

the physiology of Oenococcus oeni from wine. Journal of Applied Microbiology, 88, 1065-1071. http://dx.doi.org/10.1046/j.1365-2672.2000.01075.x

Rodríguez-Bencomo, J. J., Muñoz-González, C., Andujar-Ortiz, I., Martín-Álvarez, P. J., Moreno-Arribas, M. V., \& Pozo-Bayón, M. A. (2011). Assessment of the effect of the non-volatile wine matrix on the volatility of typical wine aroma compounds by headspace solid phase microextraction/gas chromatography analysis. Journal of the Science of Food and Agriculture, 91, 2484-2494. http://dx.doi.org/10.1002/jsfa.4494

Sáenz-Navajas, M. P., Avizcuri, J. M., Ferreira, V., \& Fernández-Zurbano, P. (2012). Insights on the chemical basis of the astringency of Spanish red wines. Food Chemistry, 134, 1484-1493. http://dx.doi.org/10.1016/j.foodchem.2012.03.060

Santos, M. C., Nunes, C., Saraiva, J. A., \& Coimbra, M. A. (2012). Chemical and physical methodologies for the replacement/reduction of sulfur dioxide use during winemaking: Review of their potentialities and limitations. European Food Research and Technology, 234, 1-12. http://dx.doi.org/10.1007/s00217-011-1614-6

Singleton, V. L., \& Rossi, J. A. (1965). Colorimetry of total phenolics with phosphomolybdic-phosphotungstic acid reagents. American Journal of Enology and Viticulture, 16, 144-158.

Ugliano, M., Genovese, A., \& Moio, L. (2003). Hydrolysis of wine aroma precursors during malolactic fermentation with four commercial starter cultures of Oenococcus oeni. Journal of Agricultural and Food Chemistry, 51, 5073-5078. http://dx.doi.org/10.1021/jf0342019

Zea, L., Moyano, L., Moreno, J. Cortes, B., \& Medina, M. (2001). Discrimination of the aroma fraction of Sherry wines obtained by oxidative and biological ageing. Food Chemistry, 75, 79-84. http://dx.doi.org/10.1016/S0308-8146(01)00190-X

\section{Copyright Disclaimer}

Copyright for this article is retained by the author(s), with first publication rights granted to the journal.

This is an open-access article distributed under the terms and conditions of the Creative Commons Attribution license (http://creativecommons.org/licenses/by/3.0/). 